\title{
The Solubility of Water in Liquid $\mathrm{CaO}-\mathrm{SiO}_{2}$ with $\mathrm{Al}_{2} \mathrm{O}_{3}, \mathrm{TiO}_{2}$, and $\mathrm{FeO}$ at $15500^{\circ} \mathrm{C}^{*}$
}

\author{
By Yasutaka IGUCHI, ${ }^{* *}$ Shiro BAN-YA, ${ }^{* * *}$ and Tasuku FUWA $A^{* * *}$
}

\section{Synopsis}

The solubility of water of silicate melts equilibrated with a given partial pressure of water vapour in an argon stream was determined by a modified vacuum fusion technique. The effects of temperature on the solubility of water in the silicate melt, and also the effects of the addition of $\mathrm{Al}_{2} \mathrm{O}_{3}$, $\mathrm{TiO}_{2}, \mathrm{~B}_{2} \mathrm{O}_{3}, \mathrm{P}_{2} \mathrm{O}_{5}$, and $\mathrm{GeO}_{2}$ on the solubility of water in a given basic silicate were studied. The same type of study was extended to the ternary system of $\mathrm{CaO}-\mathrm{SiO}_{2}-\mathrm{Al}_{2} \mathrm{O}_{3}, \mathrm{CaO}-\mathrm{SiO}_{2}-\mathrm{TiO}_{2}$, and $\mathrm{CaO}-\mathrm{SiO}_{2}-\mathrm{FeO}$ whose melting point is below $1500^{\circ} \mathrm{C}$.

\section{Introduction}

In the previous paper, ${ }^{11}$ the solubility of water in liquid synthetic slags equilibrated with the gas mixture of argon and water vapour was studied. It was confirmed that the solubility of water in silicate melts is proportional to the square root of water vapour pressure in atmosphere. Also a minimum at an approximate composition of metasilicate was observed in the solubility-composition curve for the $\mathrm{CaO}-\mathrm{SiO}_{2}$ melt. Furthermore, the water solubility in highly acid side of the $\mathrm{CaO}-\mathrm{SiO}_{2}$ system increases with added acid oxides such as $\mathrm{P}_{2} \mathrm{O}_{5}, \mathrm{~B}_{2} \mathrm{O}_{3}$, and $\mathrm{GeO}_{2}$, and the addition of amphoteric oxides such as $\mathrm{Al}_{2} \mathrm{O}_{3}$ and $\mathrm{TiO}_{2}$ shows adverse effect on the water solubility.

By improving sample taking and the accuracy of determining the solubility of water in oxide melts, these lines of work could be extended to the basic slag and also to the $\mathrm{CaO}-\mathrm{SiO}_{2}-\mathrm{Al}_{2} \mathrm{O}_{3}$ system, the $\mathrm{CaO}-\mathrm{SiO}_{2}-$ $\mathrm{TiO}_{2}$ system, and the $\mathrm{CaO}-\mathrm{SiO}_{2}-\mathrm{FeO}$ system whose melting points are lower than $1500^{\circ} \mathrm{C}$.

\section{Experimental Apparatus for Equilibrating Oxide Melt with Gas Mixtures}

The apparatus, as a schematic diagram in Fig. 1 shows, was designed for the previous work, but a hydrogen generator and microgas control-flowmeter were attached for this work. As the carrier gas, not only argon, but also argon and a small amount of hydrogen, controlled by electrolysis of $33 \% \mathrm{KOH}$ aqueous solution, were used. The water vapour in the gas mixture was controlled by passing it through a water-saturator, held in the oil bath at the given temperature, and the temperature of the oil bath was controlled within $\pm 0.1^{\circ} \mathrm{C}$ by means of a mercurytoluene regulator. The water saturator was checked up to $85^{\circ} \mathrm{C}$ with argon of the range of flowrate from 80 to $100 \mathrm{ml} / \mathrm{min}$. The water vapour pressure observed agreed with published values ${ }^{2)}$ with the accuracy of this experimental work.

Instead of a $40 \%$ rhodium platinum wire-wound resistance furnace as in the previous work, a silicon carbide spiral resistance furnace was designed for melting oxide samples in a platinum crucible which has an inner volume of about $15 \mathrm{ml}$. The temperature of the furnace could be controlled within $\pm 5^{\circ} \mathrm{C}$ at the temperature range of $1550^{\circ}$ to $1600^{\circ} \mathrm{C}$. (Fig. 2)

About $20 \mathrm{~g}$ of prepared oxides with a given com-

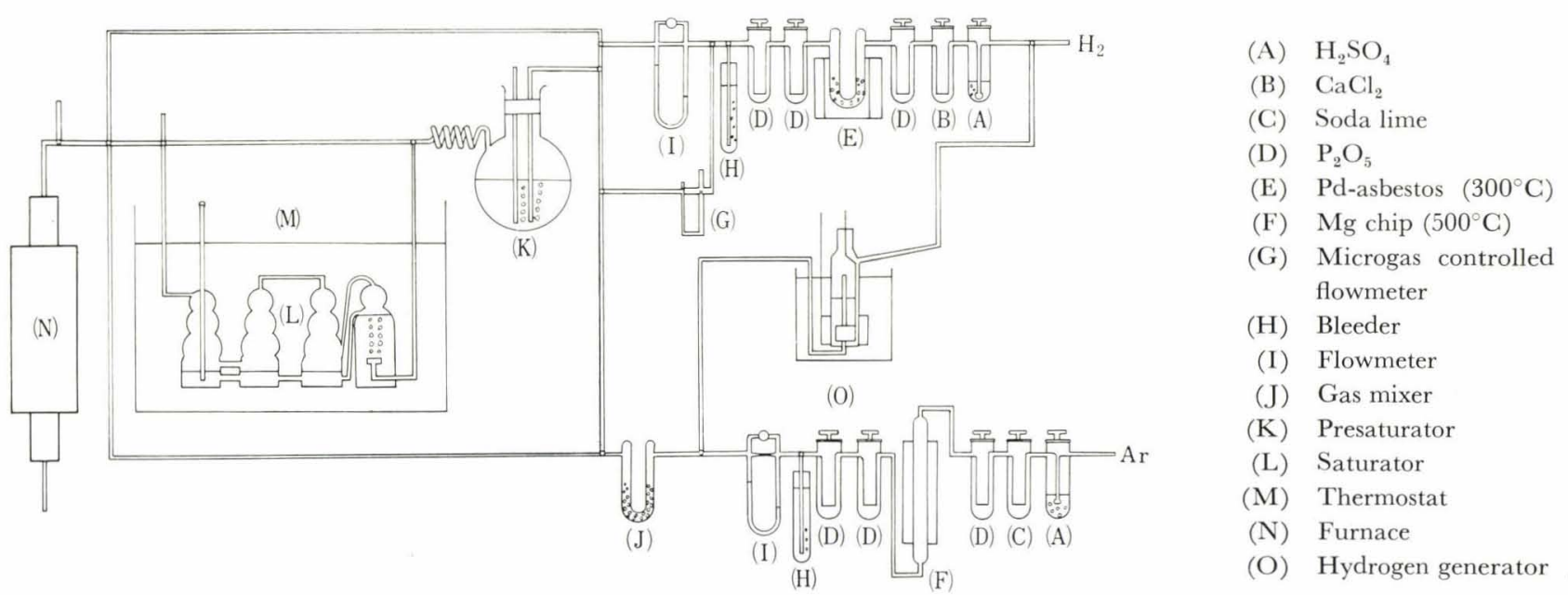

Fig. 1. Schematic diagram of apparatus for the reaction of silicate melt with gas mixtures containing water vapour

* Presented at the Joint Symposium of U.S.S.R. and Japan on Physical Chemistry of Metallurgical Processes, May, 1967 in Moscow. Manuscript received August 22, 1968.

** Graduate Student, Department of Metallurgy, Tohoku University, Aobayama, Sendai 980.

*** Department of Metallurgy, Tohoku University, Aobayama, Sendai 980. 


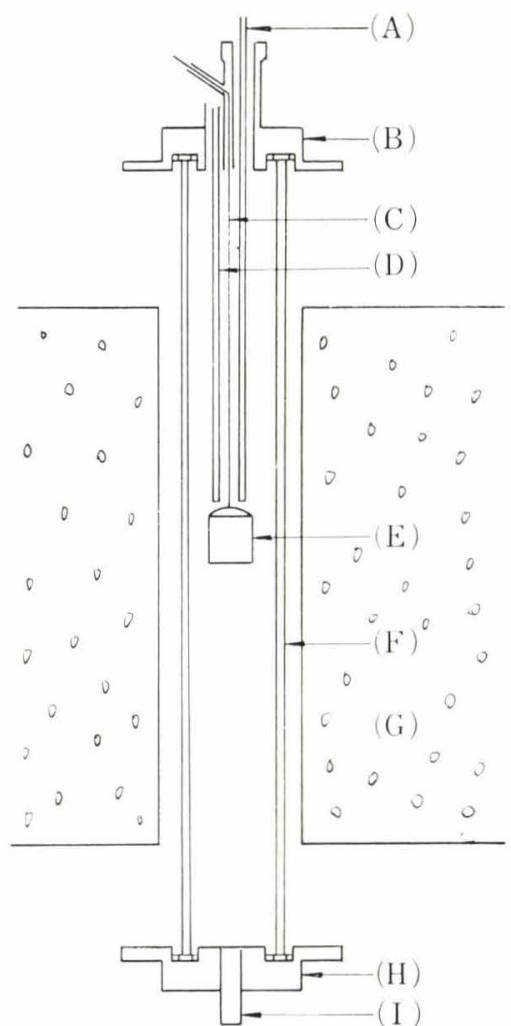

(A) Gas inlet alumina tube (B) Brass cap (C) Suspention $\mathrm{Pt}(\mathrm{Rh} 13 \%$ ) wire (D) Thermocouple (E) Pt-crucible

(F) Alumina furnace tube (G) SiC resistance furnace (H) Brass cap (I) Gas outlet

Fig. 2. Furnace assembly for the reaction of slags with gas mixtures

position are placed in the platinum crucible. The crucible is suspended by a $0.5 \mathrm{~mm}$ diameter $-13 \%$ rhodium-platinum wire in the central part of the reaction tube at a uniform temperature in the furnace. Then the oxide melt is equilibrated with the argonwater vapour mixture of a given composition at a given temperature for about $6 \mathrm{hr}$ until equilibrium is attained. The flowrate of argon is $100 \mathrm{ml} / \mathrm{min}$ or $80 \mathrm{ml}$ /min when hydrogen is added to argon. After reaching equilibrium, the platinum crucible is picked up from the top of the reaction tube, and the oxide melt is immediately cast into the water-cooled copper flat mould. Quenching into a mould from melt takes 3 to $5 \mathrm{sec}$. In the previous work, the oxide melt was lowered to the bottom of the reaction tube, and then rapidly poured out into a canal made of a thick copper plate. This casting method limited the study to acidnatured oxides. The improved sample casting method made study possible on basic-natured oxides, because glassy and no-blowhole samples could be taken. The shape of sample obtained was a disc about $2 \mathrm{~mm}$ thick. These samples were stored in clean bottles made of polyethylene in a vacuum desiccator for analysis. No significant difference in determined water content was observed even in the sample held in the desiccator for a month.

\section{Preparation of Synthetic Oxide Melt}

All the oxides used in this work were reagent grade

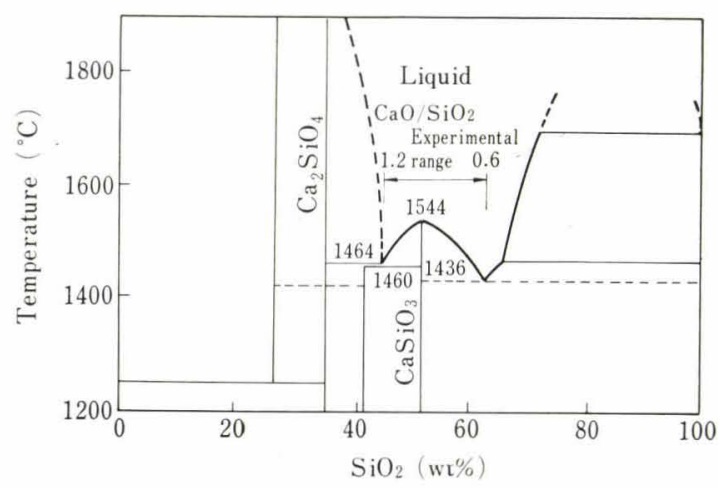

Fig. 3. Phase diagram of $\mathrm{CaO}-\mathrm{SiO}_{2}$ system

chemicals except silica, which was transparent high purity silica ground under the size of 100 mesh and washed and cleaned (over 99.9\% $\quad \mathrm{SiO}_{2}$ ), $\mathrm{FeO}$ was prepared by heating ferrous oxalate at $500^{\circ} \mathrm{C}$ for $5 \mathrm{hr}$ in the argon stream.

At the beginning of this work, mother silicates consisting of $\mathrm{CaO}$ and $\mathrm{SiO}_{2}$ were prepared. As Fig. 3 shows, there is a limited range whose melting point is lower than $1600^{\circ} \mathrm{C}$ in the $\mathrm{CaO}-\mathrm{SiO}_{2}$ system-between $55 \% \mathrm{CaO}-45 \% \mathrm{SiO}_{2}$ and $37 \% \mathrm{CaO}-63 \% \mathrm{SiO}_{2}$ by weight. The five different compositions of the CaO$\mathrm{SiO}_{2}$ mixture were prepared, being divided equally into five in this concentration range. These mixtures were held in a graphite crucible at $2000^{\circ} \mathrm{C}$ for $30 \mathrm{~min}$ by induction heating, cast on the copper plate, ground into the size of 20 to 30 mesh. After magnetic separation, these mother silicates in an alumina crucible were heated at $1000^{\circ} \mathrm{C}$ in the air to remove graphite. To these five mother silicates, a given amount of $\mathrm{Al}_{2} \mathrm{O}_{3}$, $\mathrm{P}_{2} \mathrm{O}_{5}, \mathrm{TiO}_{2}, \mathrm{~B}_{2} \mathrm{O}_{3}$, and $\mathrm{FeO}$ were added respectively and melted so that the sample could be equilibrated with water vapour. According to the chemical analysis of these prepared samples, the accuracy of the chemical composition after preparation was with $\pm 1 \%$ as was intended.

\section{Determination of Water Dissolved in Oxide Melts}

The standard vacuum fusion method apparatus for the determination of the amount of oxygen in steel was modified to determine the water dissolved in the oxide melt.

The oxide sample is melted with metallic aluminium in an alumina crucible in a vacuum reaction chamber. The released water vapour is reduced to hydrogen, and then hydrogen is volumetrically determined by microOrsat gas analyser. The apparatus finally adopted is schematically shown in Figs. 4 and 5. A molybdenum wire ( 1.0 to $1.2 \mathrm{~mm}$ dia, 6 to $8 \mathrm{~m}$ long) resistance furnace was installed to melt the oxide sample in the reaction chamber. Molybdenum wire was carefully coated with aluminium paste, and the ceramic assembly in the reaction chamber was baked out in vacuum at a temperature of over $1700^{\circ} \mathrm{C}$ for $20 \mathrm{hr}$ to evacuate volatile matter and to lower the collected gas down to below $0.05 \mathrm{~m} l$ for $20 \mathrm{~min}$.

The weighed oxide samples for each were wrapped 
in aluminium foil, $0.012 \mathrm{~mm}$ in thickness, which acts as a reducing agent. And 8 to 10 pieces of these samples were held into the sample storage tube of the reaction chamber.

The aluminium foil was carefully washed in benzine and then degassed in a vacuum at $500^{\circ} \mathrm{C}$ for about $10 \mathrm{hr}$ until the gas content in the aluminium foil was decreased to below $0.1 \mathrm{~m} l$ of gas per $1 \mathrm{~g}$ of aluminium. An amount of added aluminium must be enough to reduce all water vapour to hydrogen. Based on the results obtained in the previous work aluminium foil of about 0.1 to $0.2 \mathrm{~g}$ was used for $1 \mathrm{~g}$ oxide sample.

Then a further baking-out was needed for a new alumina crucible at $1700^{\circ} \mathrm{C}$ for 5 to $8 \mathrm{hr}$, to reach up to $10^{-5} \mathrm{mmHg}$. Following this the temperature was lowered to $1550^{\circ}$ to $1600^{\circ} \mathrm{C}$, right after $0.1 \mathrm{~g}$ aluminium was dropped into the alumina crucible. This addition of aluminium is helpful to get a good reproducibility. And the reaction chamber was evacuated below $10^{-5} \mathrm{mmHg}$ before the first sample was dropped into the crucible. Otherwise, the first sample was determined a little lower in hydrogen content.

Water was extracted from liquid oxide samples at $1550^{\circ}$ to $1600^{\circ} \mathrm{C}$, but for the sample containing volatile oxide the temperature was held as close as possible to its melting point. The weight of a sample taken for analysis was determined by the anticipated water content, so that a total volume of extracted hydrogen might be in the range from 1.5 to $2.0 \mathrm{ml}$. A blank value at the operating temperature was from 0.03 to $0.04 \mathrm{ml}$ for $30 \mathrm{~min}$, which was the extraction time for an oxide sample. About $10 \mathrm{~min}$ was sufficient for releasing the whole gas in the oxide samples, but for safety the gas was extracted for $30 \mathrm{~min}$.

If caution is taken to keep the content of $\mathrm{TiO}_{2}$, $\mathrm{P}_{2} \mathrm{O}_{5}, \mathrm{~B}_{2} \mathrm{O}_{3}$, or $\mathrm{GeO}_{2}$ in the oxide melt in the alumina crucible at less than $10 \%$ through the gas analysis, the reproducibility of the determined hydrogen was improved from $\pm 5 \mathrm{ppm}$ to less than $\pm 2 \mathrm{ppm}$ for samples containing about $50 \mathrm{ppm}$ hydrogen in the previous paper.

\section{Experimental Results}

\section{The Solubility of Water in the $\mathrm{CaO}-\mathrm{SiO}_{2}$ System}

In the previous work, the solubility of water in the $\mathrm{CaO}-\mathrm{SiO}_{2}$ melt was determined with as wide range of composition as possible, where the fusing point is below $1600^{\circ} \mathrm{C}$ under $289 \mathrm{mmHg}$ water vapour-argon stream. In the results, shown in Fig. 6, the minimum value of the solubility of water was found in the composition near metasilicate of the $\mathrm{CaO}-\mathrm{SiO}_{2}$ system. However, appreciable difference was found between the curve of the solubility of water in $\mathrm{CaO}-\mathrm{SiO}_{2}$ melt here and those obtained at $1550^{\circ} \mathrm{C}$ by Walsh, Chipman, King, and Grant $^{3)}$ and by Uys and $\mathrm{King}^{4)}$ in the same system, in which the solubility of water decreases with increase of $\mathrm{SiO}_{2}$ content. On the other hand, a minimum solubility of water has also been observed in alkali silicate glass by Kurkjian and Russell. ${ }^{5}$

The effect of temperature on the solubility of water in this sytem, at $289 \mathrm{mmHg}$ water vapour pres-

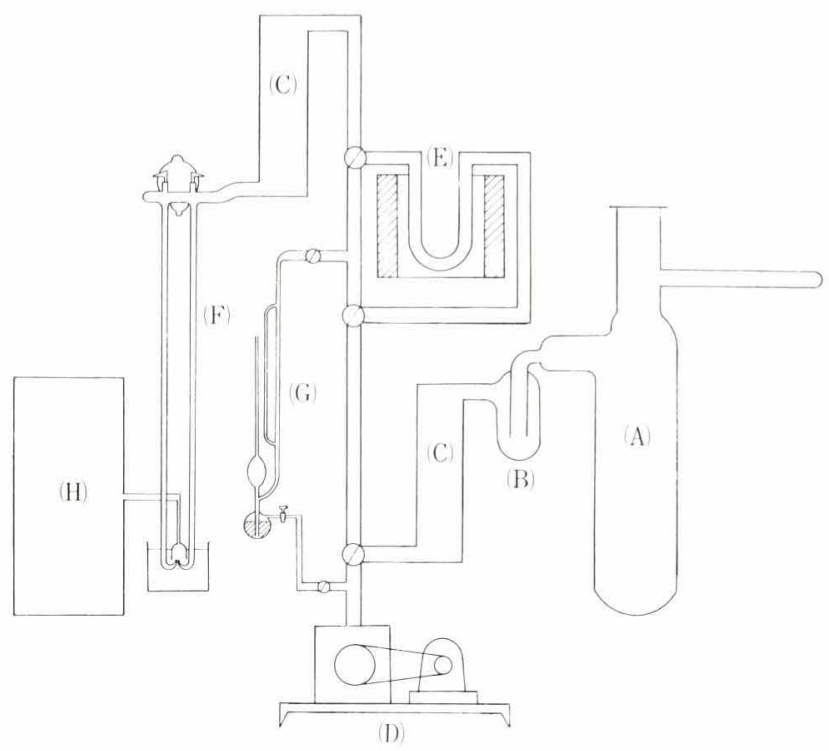

(A) Furnace (B) Dry-ice alcohol trap (C) Hg diffusion pump (D) Oil rotary pump (E) Fe-Mn (F) Sprengel pump (G) Macleod gauge (H) Micro-Orsat

Fig. 4. Schematic diagram of apparatus for water analysis of slag

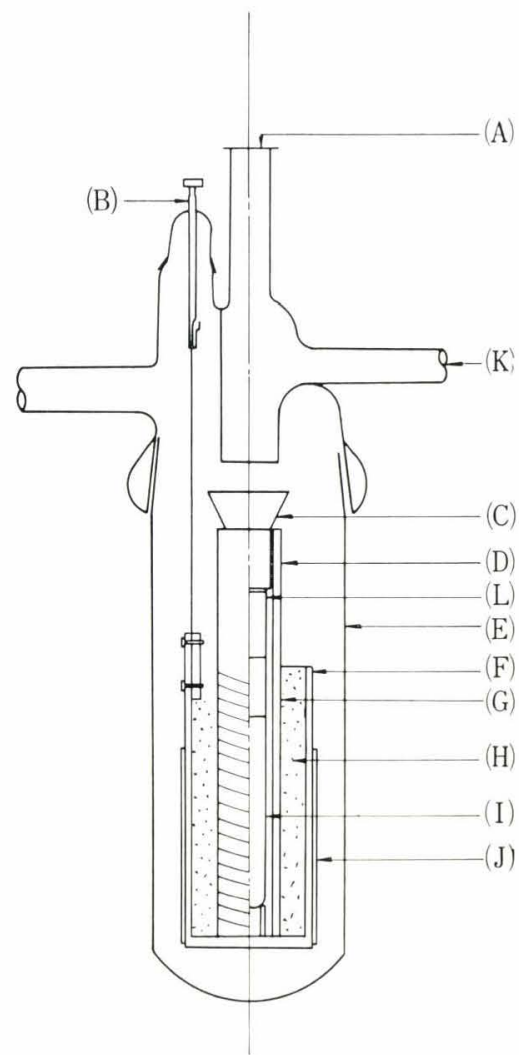

(A) Window (B) Mo-electrode (C) Mo-funnel

(D) Alumina furnace tube, $(24 \mathrm{~mm}$ i.d., $30 \mathrm{~mm}$ o.d., $250 \mathrm{~mm}$ long) (E) Silica reaction chamber (F) Alumina radiation shield (50 $\mathrm{mm}$ o.d., $200 \mathrm{~mm}$ long), (G) Mo-wire (1.0 mm d., $6 \mathrm{~m}$ long or $1.2 \mathrm{~mm} \mathrm{~d}$., $8 \mathrm{~m}$ long) (H) Alumina powder (20 to ep mesh) (I) Alumina crucible (17 mm i.d., $21 \mathrm{~mm}$ o.d.) (J) Mo-radiation plate (K) Sample storage (L) Alumina guide

Fig. 5. Furnace assembly for determination of water in slag

sure in argon, was studied in $37 \% \mathrm{CaO}-63 \% \mathrm{SiO}_{2}$ melt at $1500^{\circ}, 1550^{\circ}$, and $1600^{\circ} \mathrm{C}$, and also in $55 \%$ 


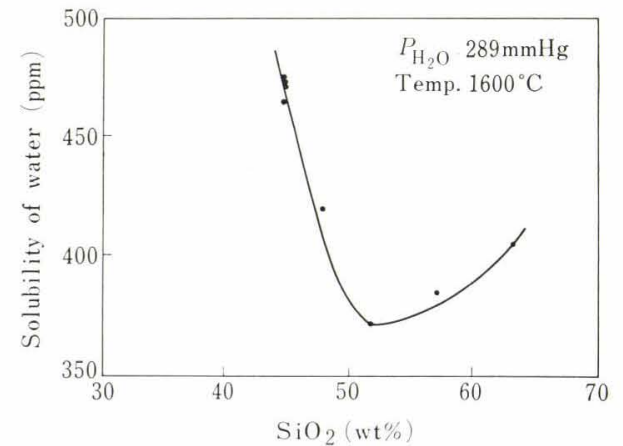

Fig. 6. Solubility of water in $\mathrm{CaO}-\mathrm{SiO}_{2}$ melts

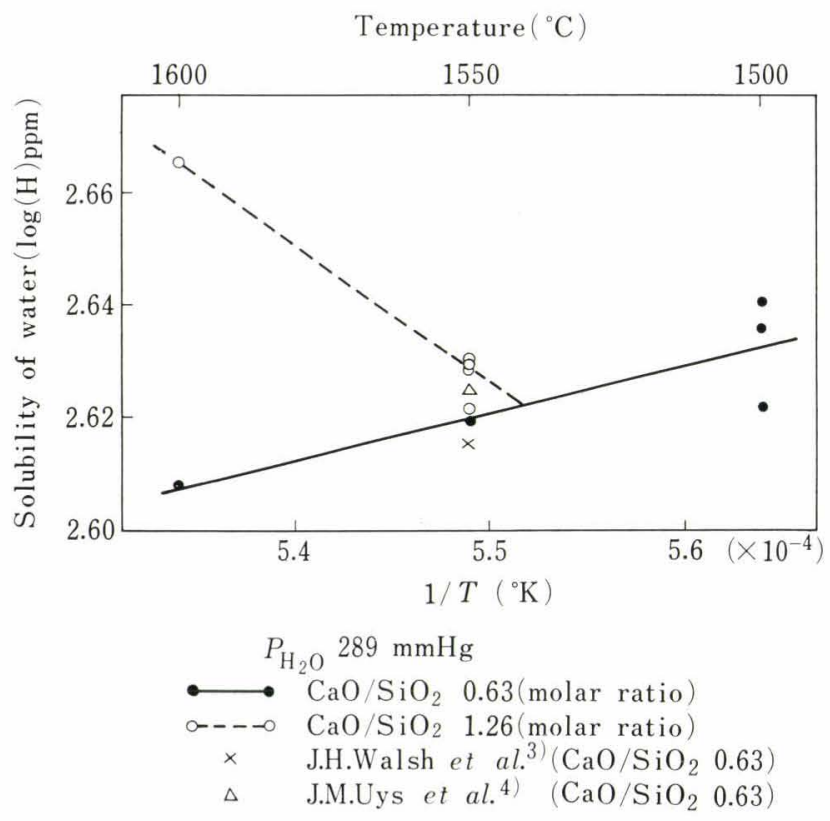

Fig. 7. Effect of temperature on solubility of water in $\mathrm{CaO}-\mathrm{SiO}_{2}$ melts

$\mathrm{CaO}-45 \% \mathrm{SiO}_{2}$ melt at $1550^{\circ}$ and $1600^{\circ} \mathrm{C}$. The results are shown in Fig. 7 as logarithm of the water content against the reciprocal of the absolute temperature. In the figure, the results calculated from the published works by other investigators ${ }^{3), 4)}$ were plotted for comparison with the present work, and a good agreement was found among them. However, the effect of temperature on acid oxide melts is contrary to that on the basic oxide melts, that is, the solubility of water in basic oxide melts increases with increasing temperature, while the water solubility in acid melts decreases with increasing temperature.

\section{Water Solubility in $\mathrm{CaO}-\mathrm{SiO}_{2}-$ Acid or Amphoteric Oxide}

In the previous paper, $\mathrm{CaO}-\mathrm{SiO}_{2}$ melt with the ratio of $\mathrm{CaO} / \mathrm{SiO}_{2}=0.59$ in weight percentage was used as the acid base oxide. In this work, $\mathrm{CaO}-\mathrm{SiO}_{2}$ melt with the ratio of $\mathrm{CaO} / \mathrm{SiO}_{2}=1.2$ in weight percentage was also used as the basic base oxide, and amphoteric oxide such as $\mathrm{Al}_{2} \mathrm{O}_{3}$ and $\mathrm{TiO}_{2}$ or acid oxide such as $\mathrm{B}_{2} \mathrm{O}_{3}, \mathrm{P}_{2} \mathrm{O}_{5}$, and $\mathrm{GeO}_{2}$ was added to the oxide to study the effect of the addition of an oxide on the solubility

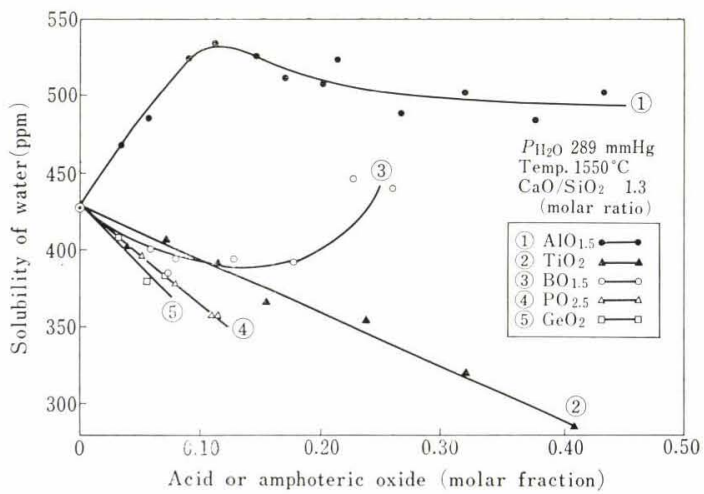

Fig. 8. Solubility of water in $\mathrm{CaO}-\mathrm{SiO}_{2}$ melts with acid or amphoteric oxides

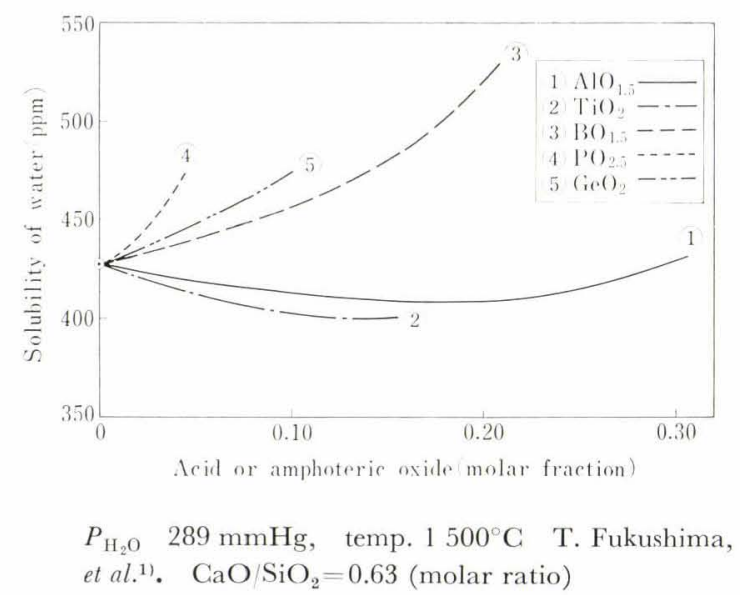

Fig. 9. Solubility of water in $\mathrm{CaO}-\mathrm{SiO}_{2}$ melts with acid or amphoteric oxides

of water in basic base oxide. Liquid silicate was equilibrated with the water vapour with the partial pressure, $P_{\mathrm{H}_{2} \mathrm{O}}=289 \mathrm{mmHg}$ at $1550^{\circ} \mathrm{C}$. The results obtained a shown in Fig. 8. From these results it was found that the addition of $\mathrm{TiO}_{2}, \mathrm{P}_{2} \mathrm{O}_{5}$, and $\mathrm{GeO}_{2}$ to the base oxide of the molar ratio of $\mathrm{CaO} / \mathrm{SiO}_{2}=1.3$ decreases the solubility of water, and the addition of $\mathrm{B}_{2} \mathrm{O}_{3}$ also decreases the water solubility, but the further addition of $\mathrm{B}_{2} \mathrm{O}_{3}$ shows a minimum value and then increases the water solubility. On the other hand, the addition of $\mathrm{Al}_{2} \mathrm{O}_{3}$ increases the water solubility and shows a maximum value at about 0.13 molar fraction of $\mathrm{Al}_{2} \mathrm{O}_{3}$ and then gradually decreases the water solubility.

Comparison of the effects of the addition of the same kind of oxide to acid base oxide of the molar ratio of $\mathrm{CaO} / \mathrm{SiO}_{2}=0.63$ is shown in Fig. 9.

\section{Effect of Hydrogen in Water Vapour-Argon Mixture on the Solubility of Water in Oxide Melts}

The effects of addition of hydrogen to argon-water vapour mixture of $80 \mathrm{ml}$ per minute on the water solubility in oxide melts with the ratio $\mathrm{CaO} / \mathrm{SiO}_{2}=1.18$ were studied at $1550^{\circ} \mathrm{C}$ at $289 \mathrm{mmHg}$ water vapour. Hydrogen was added in amount of 3, 7, and $14 \mathrm{ml} / \mathrm{min}$ to argon-water vapour mixture. However, as Walsh et al. reported, no appreciable effect was observed. 


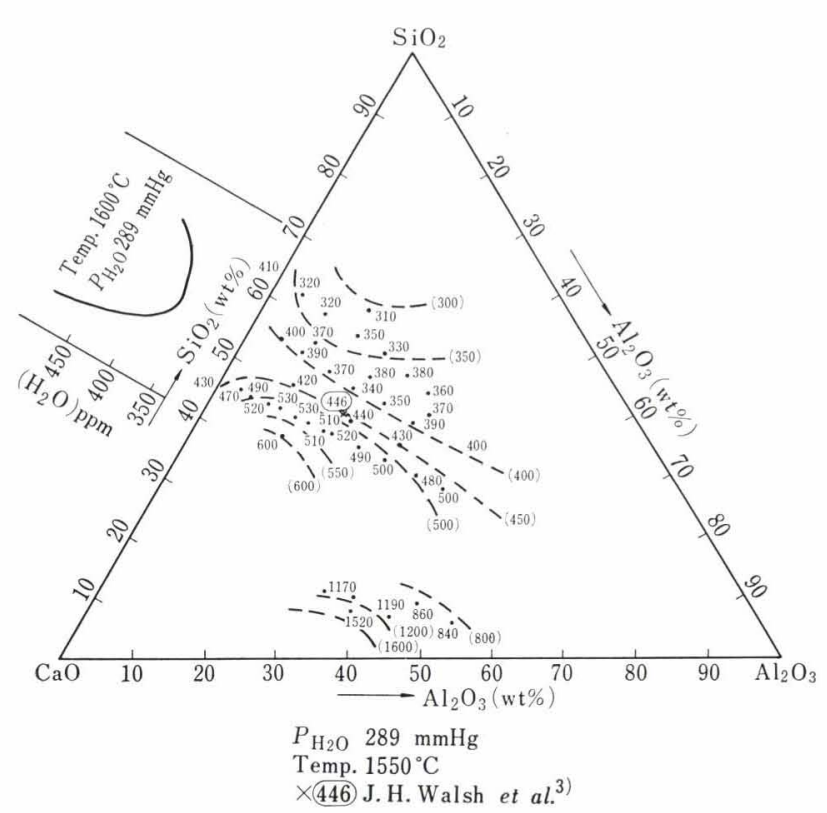

Fig. 10. Solubility of water in $\mathrm{CaO}-\mathrm{SiO}_{2}-\mathrm{Al}_{2} \mathrm{O}_{3}$ melts (ppm)

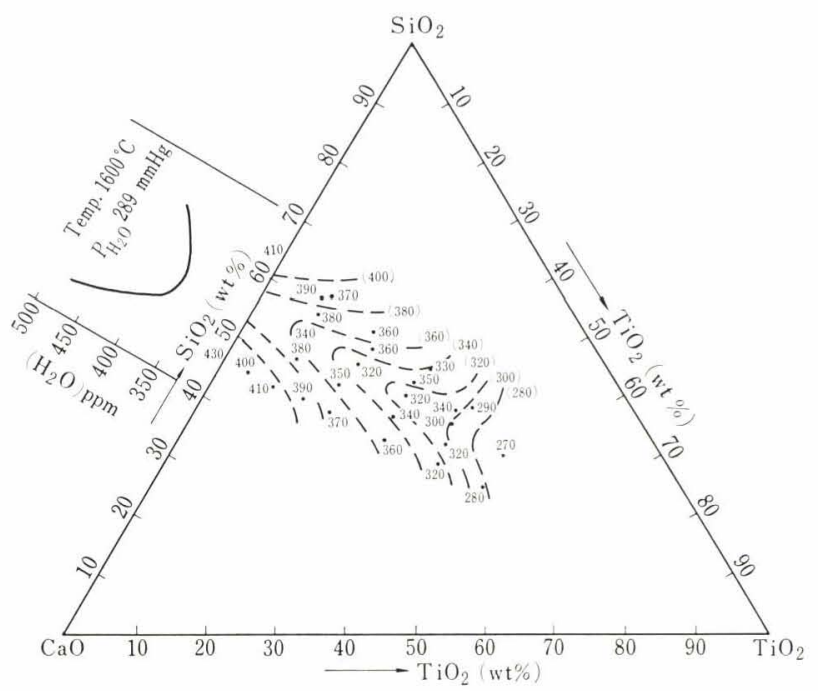

Fig. 11. Solubility of water in $\mathrm{CaO}-\mathrm{SiO}_{2}-\mathrm{TiO}_{2}$ melts (ppm) $P_{\mathrm{H}_{2} \mathrm{O}} 289 \mathrm{mmHg}$, temp. $1550^{\circ} \mathrm{C}$.

\section{Iso-concentration Curve of Water Solubility in the Ternary System}

Under $289 \mathrm{mmHg}$ water vapour-argon mixture at $1550^{\circ} \mathrm{C}$, the solubility of water in the $\mathrm{CaO}-\mathrm{SiO}_{2}-$ $\mathrm{Al}_{2} \mathrm{O}_{3}$ system, the $\mathrm{CaO}-\mathrm{SiO}_{2}-\mathrm{TiO}_{2}$ system and the $\mathrm{CaO}-\mathrm{SiO}_{2}-\mathrm{FeO}$ system were studied. The results are shown in Figs. 10, 11, and 12. In Fig. 10, the data determined by Walsh et al. at $1550{ }^{\circ} \mathrm{C}$ in $40 \% \mathrm{CaO}$ $40 \% \mathrm{SiO}_{2}-20 \% \mathrm{Al}_{2} \mathrm{O}_{3}$ melt is plotted and shows a good agreement with the present work. For the $\mathrm{CaO}-\mathrm{SiO}_{2}-$ $\mathrm{FeO}$ system, as it was clarified that hydrogen does not affect the water solubility, $2.7 \mathrm{ml}$ hydrogen per minute was added to the water vapour-argon mixture, in order to give the same oxygen potential $\left(1.5 \times 10^{-6} \mathrm{~atm}\right.$ at $1550^{\circ} \mathrm{C}$ ) and to fix the composition of " $\mathrm{FeO}$ " in oxide melt in the wüstite range (in which $P_{\mathrm{O}_{2}}=2.4 \times$

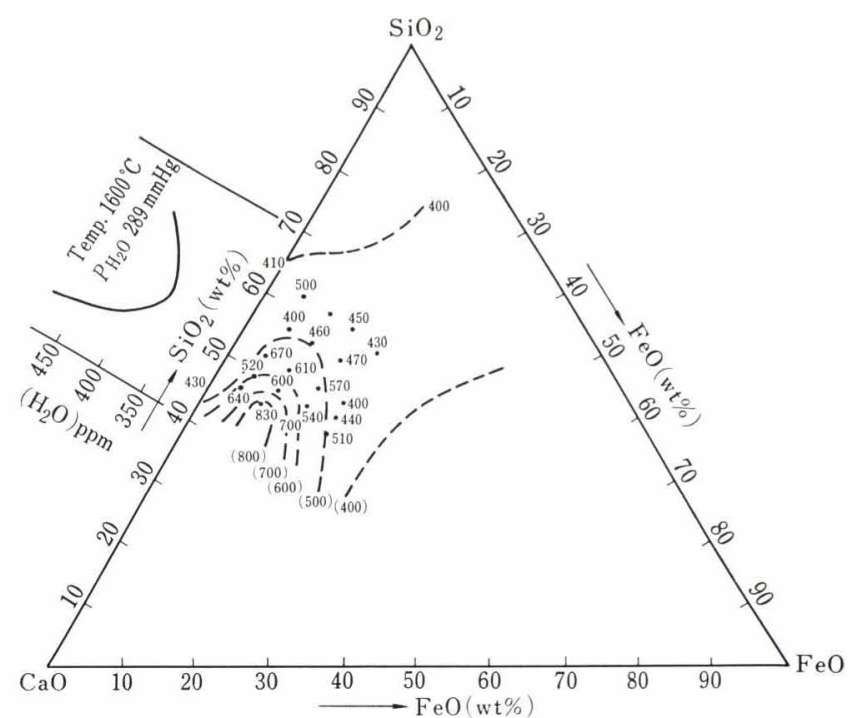

Fig. 12. Solubility of water in $\mathrm{CaO}-\mathrm{SiO}_{2}-\mathrm{FeO}$ melts (ppm) $P_{\mathrm{H}_{2} \mathrm{O}} 289 \mathrm{mmHg}$, temp. $1550^{\circ} \mathrm{C}, P_{\mathrm{O}_{2}} 1.5 \times 10^{-6} \mathrm{~atm}$.

$10^{-9} \sim 2.5 \times 10^{-6} \mathrm{~atm}$, at $1550^{\circ} \mathrm{C}$ ).

\section{Discussion}

From the results obtained by other investigators ${ }^{3), 4),}$ ${ }_{6), 7), 8)}$ and in the previous and present work, the following conclusions are drawn: The amount of water dissolved in oxide melt is proportional to the square root of the partial pressure of water vapour.

$$
(\mathrm{H})=C \sqrt{ } P_{\mathrm{H}_{2} \mathrm{O}}
$$

where, $(\mathrm{H})$ denotes the hydrogen content in oxide melt (ppm), and $P_{\mathrm{H}_{2} \mathrm{O}}$ the partial pressure of water vapour $(\mathrm{mmHg}) . \quad C$ is a constant and may change depending upon the composition of oxide and temperature.

According to infrared absorption spectroscopic studies, $\left.\left.{ }^{1,}, 9\right), 10\right)$ quenched silicates show absorption bonds of 2.7 to $3.1 \mu$ and 3.4 to $3.8 \mu$ in relation to $\mathrm{O} \cdot \mathrm{H}$ bond in silicate. Therefore, it is considered that hydrogen dissolves in silicate melt as hydroxyl ion or $\mathrm{O} \cdot \mathrm{H}$ bond. Furthermore, hydrogen in the gas phase above oxide melt does not affect the solubility of water.

Infrared absorption spectra and a minimum solubility of water in some binary silicate melts and the contrary effect of temperature on the solubility of acid melts and of basic melts suggest the possibility of different mechanism involved in the solution of water depending upon the composition. A possible mode of solution can be written by the following equations as suggested by Tomlinson, ${ }^{8)}$ Walsh et al., ${ }^{3)}$ Russell'):

Acid silicate

$$
\rightarrow \mathrm{Si}-\mathrm{O}-\mathrm{Si}<+\mathrm{H}_{2} \mathrm{O}(\mathrm{g})=>\mathrm{Si}-\mathrm{OH} \mathrm{HO}-\mathrm{Si}<\ldots
$$

Basic silicate

$$
\begin{aligned}
& \rightarrow \mathrm{Si}-\mathrm{O}^{-\mathrm{Cation}^{2+} \mathrm{O}^{-}-\mathrm{Si}} \leftarrow+\mathrm{H}_{2} \mathrm{O}(\mathrm{g}) \\
& \quad=\rightarrow \mathrm{Si}-\mathrm{O}-\mathrm{Si}<+ \text { Cation }^{2+}+2\left(\mathrm{OH}^{-}\right)
\end{aligned}
$$


or

$$
\begin{aligned}
& \left(\rightarrow \mathrm{Si}-\mathrm{O}^{\left.-\mathrm{Cation}^{2+} \mathrm{O}^{-}-\mathrm{Si}<\right)}+\mathrm{H}_{2} \mathrm{O}\right. \\
& \quad=(\rightarrow \mathrm{Si}-\mathrm{OH} \mathrm{HO}-\mathrm{Si}<)+\text { Cation }^{2+}+\mathrm{O}^{2-}
\end{aligned}
$$

Highly basic silicate

$$
\mathrm{O}^{2-}+\mathrm{H}_{2} \mathrm{O}(\mathrm{g})=2\left(\mathrm{OH}^{-}\right)
$$

In these modes of solution, water behaves in a fashion similar to a basic oxide against an acid silicate, that is, it breaks a network structure in reaction with doublybonded oxygen in silicate, and it also acts as an acid oxide against a basic silicate.

Although several different definitions have been offered on basicity and acidity of oxides, the ion-oxygen attraction of cation, which is defined as $I=2 Z^{+} / a^{2}$ (where $Z^{+}$is the cation valency, and $a$ is the internuclear distance) probably may be sufficient to explain these properties of oxide. The ion-oxygen attraction of cation in some oxides related to the present study is listed in Table 1; the ion-oxygen attraction of water is between that of acid oxide and of basic oxide. This fact suggests the possibility that water may behave as an amphoteric oxide depending upon the composition of silicate melt.

Table 1. Ion-oxygen attraction in oxides

\begin{tabular}{c|llc}
\hline Oxide & $\begin{array}{c}\text { Ion-oxygen } \\
\text { attraction }\end{array}$ & Oxide & $\begin{array}{c}\text { Ion-oxygen } \\
\text { attraction }\end{array}$ \\
\hline $\mathrm{P}_{2} \mathrm{O}_{5}$ & 3.31 & $\mathrm{Fe}_{2} \mathrm{O}_{3}$ & 1.50 \\
$\mathrm{SiO}_{2}$ & 2.44 & $\mathrm{H}_{2} \mathrm{O}$ & 1.05 \\
$\mathrm{~B}_{2} \mathrm{O}_{3}$ & 2.34 & $\mathrm{MgO}$ & 0.95 \\
$\mathrm{GeO}_{2}$ & 2.14 & $\mathrm{FeO}$ & 0.87 \\
$\mathrm{TiO}_{2}$ & 1.85 & $\mathrm{CaO}$ & 0.70 \\
$\mathrm{Al}_{2} \mathrm{O}_{3}$ & 1.66 & $\mathrm{NaO}$ & 0.36 \\
\hline
\end{tabular}

Although the interpretation given above concerns the water solubility of silicate melts containing silica only as an acid component, the mechanism of solution of water in the synthetic oxide melt containing many kinds of acid oxide will be considered as follows: Oxygen in liquid oxide takes only three forms, doublybonded $\mathrm{O}^{\circ}$ (bridging oxygen), simply-bonded $\mathrm{O}^{-}$ (bonding oxygen ion), and free oxygen ion $\mathrm{O}^{2-}$, as suggested by Fincham and Richardson. ${ }^{11)}$ These three kinds of oxygen in oxide melt equilibrate with each other depending upon melting temperatures, the characteristic of cation and the composition of oxide. The polymerization in oxide melt is very complicated and the concentration of the three forms of oxygen in oxide melt could not be determined. However, since water reacts with these three kinds of oxygen in oxide melt according to different mechanisms of solution respectively, they may be expressed by the following equations :

In the acid oxide melts,

$$
(\mathrm{O})+\mathrm{H}_{2} \mathrm{O}(\mathrm{g})=2(\mathrm{OH})
$$

In the basic oxide melt, or

$$
\begin{aligned}
& 2\left(\mathrm{O}^{-}\right)+\mathrm{H}_{2} \mathrm{O}(\mathrm{g})=\mathrm{O}+2\left(\mathrm{OH}^{-}\right) \\
& 2\left(\mathrm{O}^{-}\right)+\mathrm{H}_{2} \mathrm{O}(\mathrm{g})=\mathrm{O}^{2-}+2(\mathrm{OH})
\end{aligned}
$$

In the highly basic slag,

$$
\left(\mathrm{O}^{2-}\right)+\mathrm{H}_{2} \mathrm{O}(\mathrm{g})=2\left(\mathrm{OH}^{-}\right)
$$

In the region of acid oxide melts, reaction (5) is expressed by the predominant mechanism of solution, and water solubility may be proportional to the activity of the doubly-bonded oxygen which increases with increasing concentration of acid oxide in slag.

In the region of somewhat more basic oxide melts, reaction (6) is considered to be predominant, and water solubility in this region may be increased with decreasing content of acid oxide. The variation of water solubility with composition can be qualitatively determined by the sum of the contributions of the above two mechanisms of solution.

Minimum solubility of water in the $\mathrm{CaO}-\mathrm{SiO}_{2}$ system suggests that the mechanism of solution is different in the basic side from the acid side near the composition of metasilicate as the transition point, and this phenomenon is explained in reactions of (5), (6), and $\left(6^{\prime}\right)$. The transition point is affected by the kinds of oxides of the system, chemical composition, and by temperature.

As the effect of temperature on water solubility in oxide melts were determined as shown in Fig. 7, the slope between the logarithm of water content $(\log (\mathrm{H})$ ppm) and the reciprocal of the absolute temperature $(1 / T)$ will give the heat of the solution of water into acid oxide me lt $\left(37 \% \mathrm{CaO}-63 \% \mathrm{SiO}_{2}\right.$ melt) as -7.3 $\mathrm{kcal} / \mathrm{mol}$ or basic oxide melt $\left(55 \% \mathrm{CaO}-45 \% \mathrm{SiO}_{2}\right.$ melt) as $21.5 \mathrm{kcal} / \mathrm{mol}$.

In the region of acid oxide melts, doubly-bonded oxygen decreases with increasing temperature, while in the region of basic oxide melts, simply-bonded oxygen ion $\mathrm{O}^{-}$increases with increasing temperature, and the bonding in the melt becomes simpler, like $\rightarrow \mathrm{Si}-\mathrm{O}-\mathrm{Si}<\rightarrow \mathrm{Si}_{-} \mathrm{O}^{-}$, as it was interpreted for other physical properties of melt, for example viscosity.

The water solubility in $\mathrm{CaO}-\mathrm{SiO}_{2}$-amphoteric and acid oxide melts, with the molar ratio of $\mathrm{CaO}$ to $\mathrm{SiO}_{2}$ constant $\left(\mathcal{N}_{\mathrm{CaO}} / \mathcal{N}_{\mathrm{SiO}_{2}}=1.3\right)$ was studied as shown in Fig. 8. In comparison with these results, those of the same kind of study in the previous work at the constant ratio of $\mathrm{CaO}$ to $\mathrm{SiO}_{2}$ in molar fraction $\left(\mathcal{N}_{\mathrm{CaO}} / \mathcal{N}_{\mathrm{SiO}_{2}}=\right.$ 0.63) are shown in Fig. 9.

As the oxide melts in this work are weak basic, the reaction with water vapour may be predominant by reactions (6) and $\left(6^{\circ}\right)$. Therefore, the addition of $\mathrm{Al}_{2} \mathrm{O}_{3}$ increases the water solubility, because alumina may act as a basic oxide. However, the water solubility reaches a certain concentration, and then the solubility decreases as $\mathrm{Al}_{2} \mathrm{O}_{3}$ may act as an acid. $\mathrm{Al}_{2} \mathrm{O}_{3}$ apparently shows amphoteric behaviour.

The addition of $\mathrm{TiO}_{2}$ to the $\mathrm{CaO}-\mathrm{SiO}_{2}$ melt is not as large as the addition of $\mathrm{Al}_{2} \mathrm{O}_{3}$. As will be mentioned later in the ternary system which contains $\mathrm{TiO}_{2}$, the effect of $\mathrm{TiO}_{2}$ on water solubility is small. However, 
by the addition of $\mathrm{TiO}_{2}$ the relative amount of $\mathrm{CaO}-$ $\mathrm{SiO}_{2}$ is reduced per unit weight. Therefore, it seems as if the solubility is decreased by the addition of $\mathrm{TiO}_{2}$. The addition of an acid oxide such as $\mathrm{B}_{2} \mathrm{O}_{3}, \mathrm{P}_{2} \mathrm{O}_{5}$, or $\mathrm{GeO}_{2}$ decreases the water solubility, because these oxides may act as acid and by reaction (6) bonding oxygen ion $\mathrm{O}^{-}$will be decreased. However, if the addition of acid oxide is beyond a certain amount, reaction (5) rather than reaction (6) becomes gradually predominant, and water solubility may be expected to increase, as was found in the $\mathrm{CaO}-\mathrm{SiO}_{2}-\mathrm{B}_{2} \mathrm{O}_{3}$ system. In the case of the addition of $\mathrm{P}_{2} \mathrm{O}_{5}$ or $\mathrm{GeO}_{2}$, because of high viscosity and high melting point of the silicates, neither could check the tendency mentioned above.

The iso-concentration curve of water solubility of the ternary system was obtained, as shown in Figs. 10, 11 , and 12 .

In the $\mathrm{CaO}-\mathrm{SiO}_{2}-\mathrm{Al}_{2} \mathrm{O}_{3}$ system, it was clarified that the role played by the addition of $\mathrm{Al}_{2} \mathrm{O}_{3}$ is completely opposite in the acid side and in the basic side and the border of the composition is near the metasilicate. That is, in the acid side, the addition of $\mathrm{Al}_{2} \mathrm{O}_{3}$ decreases the water solubility which shows a minimum solubility and then increases by the further addition of $\mathrm{Al}_{2} \mathrm{O}_{3}$. On the other hand, in the basic side, on the contrary, the addition of $\mathrm{Al}_{2} \mathrm{O}_{3}$ increases the water solubility, which shows a maximum solubility and then shows the tendency to decrease. In general, as $\mathrm{Al}_{2} \mathrm{O}_{3}$ to amphoteric, the addition of a considerable amount of $\mathrm{Al}_{2} \mathrm{O}_{3}$ makes the solubility curve flatter. The composition of the melt at the maximum solubility corresponds to near the orthosilicate composition of $(\mathrm{CaO}$ $+\mathrm{Al}_{2} \mathrm{O}_{3}$ ).

In the $\mathrm{CaO}-\mathrm{SiO}_{2}-\mathrm{TiO}_{2}$ system, it seemed that the addition of $\mathrm{TiO}_{2}$ plays only the role of dilution of the water solubility in the $\mathrm{CaO}-\mathrm{SiO}_{2}$ system. Beyond the certain amount of $\mathrm{TiO}_{2}$ added, $\mathrm{TiO}_{2}$ shows amphoteric nature in relation to the $\mathrm{CaO}-\mathrm{SiO}_{2}$ system and the minimum solubility will disappear by increasing the addition of $\mathrm{TiO}_{2}$.

In the $\mathrm{CaO}-\mathrm{SiO}_{2}-\mathrm{FeO}$ system, the addition of " $\mathrm{FeO} "$ to the $\mathrm{CaO}-\mathrm{SiO}_{2}$ system first increases the water solubility and shows the maximum solubility, then decreases.

From the rank of ion-oxygen attraction, as shown in Table 1, "FeO" was considered to act as a base and was expected to increase the water solubility. However, the result obtained is interpreted as showing that the oxygen potential of the gas phase $\left(1.5 \times 10^{-6} \mathrm{~atm}\right)$ is close to the equilibrium oxygen pressure $\left(2.5 \times 10^{-6}\right.$ atm at $1550^{\circ} \mathrm{C}$ ) with " $\mathrm{FeO} "-\mathrm{Fe}_{2} \mathrm{O}_{3}$. Because of the increasing activity of " $\mathrm{FeO}$ ", a part of " $\mathrm{FeO}$ " may be oxidized to $\mathrm{Fe}_{2} \mathrm{O}_{3}$, the original nature of " $\mathrm{FeO}$ " was decreased by the appearance of $\mathrm{Fe}_{2} \mathrm{O}_{3}$, resulting in decreasing the water solubility.

In order to solve this problem, further study has been undertaken.

\section{Summary}

A vacuum fusion technique was applied to determine the solubility of water in synthetic silicate melts equilibrated with the gas mixture of water vapour-argon. The average variation of determined hydrogen was usually $\pm 2 \mathrm{ppm}$ to an oxide sample with about $50 \mathrm{ppm}$ hydrogen.

The results obtained are as follows:

(1) A minimum at an approximate composition of metasilicate was observed in the solubility-composition curve for the $\mathrm{CaO}-\mathrm{SiO}_{2}$ melt.

(2) The effect of temperature on the solubility of water shows contrary tendencies in acid silicate melts (the molar ratio of $\mathrm{CaO}$ to $\mathrm{SiO}_{2}$ is 0.63 ) to basic silicate melts (the molar ratio is 1.26 )

(3) The effect of the addition of $\mathrm{Al}_{2} \mathrm{O}_{3}, \mathrm{TiO}_{2}$, $\mathrm{B}_{2} \mathrm{O}_{3}, \mathrm{P}_{2} \mathrm{O}_{5}$, and $\mathrm{GeO}_{2}$ on the water solubility in the basic silicate melt with the molar ratio of $\mathrm{CaO}$ to $\mathrm{SiO}_{2}$ 1.3 was determined at $1550^{\circ} \mathrm{C}$ as shown in Fig. 8 .

(4) The addition of hydrogen in the gas mixture of water vapour and argon did not affect the solubility of water in the silicate melts equilibrated with the gas mixture without the addition of hydrogen.

(5) The solubility of water in the ternary silicate melts of $\mathrm{CaO}-\mathrm{SiO}_{2}-\mathrm{Al}_{2} \mathrm{O}_{3}, \mathrm{CaO}-\mathrm{SiO}_{2}-\mathrm{TiO}_{2}$, and of $\mathrm{CaO}-\mathrm{SiO}_{2}-\mathrm{FeO}$ was determined at $1550^{\circ} \mathrm{C}$ as shown in Figs. 10, 11, and 12.

\section{Acknowledgement}

The authors want to express their appreciation to Mr. H. Hayakawa and Mr. H. Mine for their assistance in the achievement of this study.

\section{REFERENCES}

1) T. Fukushima, Y. Iguchi, S. Ban-ya, and T. Fuwa: Trans. ISIJ, 6 (1966), 225.

2) Japan Chemical Society: Handbook of Chemistry, (1958).

3) J. H. Walsh, J. Chipman, T. B. King, and N. J. Grant: J. Metals, 8 (1956), 1568.

4) J. N. Uys and T. B. King: Trans. Met. Soc. AIME, 227 (1963) 492.

5) C. R. Kurkjian and L. E. Russell: J. Soc. Glass. Tech., 42 (1958), 130T.

6) M. Imai, H. Ooi, and T. Emi: Tetsu-to-Hanané, 48 (1962), 111.

7) L. E. Russell: J. Soc. Glass Tech., 41 (1957), 304T.

8) J. W. Tomlinson: J. Soc. Glass Tech., 40 (1956), $25 \mathrm{~T}$.

9) H. Scholze: Glass Tech. Ber., 32 (1959), 81; 142.

10) M. Imai, H. Ooi, and T. Emi: Tetsu-to-Hagané, 50 (1964), 878.

11) C. J. B. Fincham and F. D. Richardson: Proc. Roy. Soc., A 223 (1954), 40. 